\title{
УДК 336.143:332.15:353
}

https://doi.org/10.52058/2708-7530-2022-1(19)-148-158

Лопушинський Іван Петрович доктор наук 3 державного управління, професор, заслужений працівник освіти України, завідувач кафедри державного управління i місцевого самоврядування Херсонського національного технічного університету, вул. Бериславське Шосе, 24, м. Херсон, 73008, тел.: (0552) 32-69-86, https://orcid.org/0000-0002-7460-7476

Григор'єва Лідія Миколаївна здобувач третього (освітньо-наукового) рівня вищої освіти галузі знань 28 «Публічне управління та адміністрування» спеціальності 281 «Публічне управління та адміністрування» Херсонського національного технічного університету, вул. Бериславське Шосе, 24, м. Херсон, 73008, тел. (0552) 32-69-12, https://orcid.org/0000-0001-9280-9218

\section{БЮДЖЕТНО-ФІНАНСОВА ДЕЦЕНТРАЛІЗАЦІЯ В КОНТЕКСТІ РЕФОРМУВАННЯ МІСЦЕВОГО САМОВРЯДУВАННЯ В УКРАЇНІ}

Анотація. У дослідженні розглядаються теоретичні засади та практика бюджетно-фінансової децентралізації в контексті реформування місцевого самоврядування в Україні; показано, що децентралізація бюджетнофінансових повноважень на користь місцевого самоврядування наразі постає визначальною реформою останніх десятиліть існування Української держави; з'ясовано, що фінансовий аспект є одним із найсуттєвіших, від якого значною мірою залежить успішність функціонування територіальних громад; доведено, що наявність достатніх ресурсів у місцевих бюджетах $є$ запорукою того, що територіальна громада має можливість надавати більш якісні та більш різноманітні послуги своїм жителям; аналіз стану бюджетно-фінансової децентралізації в Україні дав підстави для висновків про те, що результатом реформи стало підвищення зацікавленості органів місцевого самоврядування в суттєвому збільшенні надходжень до місцевих бюджетів, пошуку резервів їх наповнення, поліпшення ефективності адміністрування податків і зборів; доведено, що наявність економічно активних суб'єктів підприємницької діяльності, достатня кількість кваліфікованих трудових ресурсів, розвинена промислова та соціальна інфраструктура - усе це та багато іншого $є$ основою для успішного розвитку громади; показано, що в частині використання коштів органами місцевого самоврядування увага акцентується на потребі формування найбільш оптимальної структури бюджетних видатків, створенні ефективного не надто чисельного управлінського апарату, здійсненні постійного аналізу витрачання бюджетних коштів й упередженні випадків їх нераціонального витрачання. 
Ключові слова: децентралізація, бюджетно-фінансова децентралізація, місцеві бюджети, територіальні громади, оптимальна структура бюджетних видатків, раціональне використання бюджетних коштів, сталий розвиток, належне життєве середовище членів територіальних громад.

Lopushynskyi Ivan Petrovych Doctor of Science in Public Administration, Professor, Honored Worker of Education of Ukraine, Head of the Department of Public Administration and Local Self-Government of Kherson National Technical University, Beryslavske Shosse, 24, Kherson, 73008, tel.: (0552) 32-69-86, https://orcid.org/0000-0002-7460-7476

Hryhorieva Lidiia Mykolaivna Candidate of the third (educational-scientific) level of higher education in the field of knowledge 28 "Public Administration and Administration" specialty 281 "Public Administration and Administration" of Kherson National Technical University, Beryslavske Shosse, 24, Kherson, 73008, tel. (0552) 32-69-12, https://orcid.org/0000-0001-9280-9218

\title{
BUDGETARY AND FINANCIAL DECENTRALIZATION IN THE CONTEXT OF LOCAL GOVERNMENT REFORM IN UKRAINE
}

\begin{abstract}
The study examines the theoretical foundations and practice of budgetary and financial decentralization in the context of local government reform in Ukraine; it is shown that the decentralization of budgetary and financial powers in favor of local self-government is currently a decisive reform of the last decades of the Ukrainian state; it was found that the financial aspect is one of the most important, on which the success of the functioning of territorial communities largely depends; it is proved that the availability of sufficient resources in local budgets is a guarantee that the local community has the opportunity to provide better and more diverse services to its residents; analysis of the state of fiscal decentralization in Ukraine led to the conclusion that the reform resulted in increased interest of local governments in significantly increasing revenues to local budgets, finding reserves to fill them, improving the efficiency of tax administration and fees; it is proved that the presence of economically active business entities, a sufficient number of skilled labor resources, developed industrial and social infrastructure - all this and much more is the basis for successful community development; It is shown that in terms of the use of funds by local governments attention is focused on the need to form the most optimal structure of budget expenditures, create an effective not very large management staff, conduct constant analysis of budget expenditures and prevent cases of irrational spending.
\end{abstract}

Keywords: decentralization, budgetary and financial decentralization, local budgets, territorial communities, optimal structure of budget expenditures, rational 
use of budget funds, sustainable development, proper living environment of members of territorial communities.

Постановка проблеми. Децентралізація владних та фінансових повноважень держави на користь місцевого самоврядування $\epsilon$ однією із найбільш визначальних реформ 3 часів української незалежності. Головним стратегічним завданням модернізації системи державного управління та територіальної організації влади, що сьогодні здійснюється, є формування ефективного місцевого самоврядування, створення комфортних умов для проживання громадян, надання їм високоякісних та доступних публічних послуг. Досягнення означених цілей неможливе без належного рівня економічного розвитку відповідних територій, їх фінансового забезпечення та достатніх джерел для наповнення місцевих бюджетів [1].

Саме бюджетно-фінансовий аспект є одним із найсуттєвіших, від якого, значною мірою залежить успішність функціонування територіальних громад. Наявність економічно активних суб'єктів підприємницької діяльності, достатня кількість кваліфікованих трудових ресурсів, розвинена промислова та соціальна інфраструктура - усе це та багато іншого є основою для успішного розвитку територіальної громади.

Результатом реформи децентралізації стало підвищення зацікавленості органів місцевого самоврядування у збільшенні надходжень до місцевих бюджетів, пошуку резервів їх наповнення, поліпшення ефективності адміністрування податків і зборів. Спроможні громади показують високі i динамічні темпи приросту власних доходів. У частині використання коштів увага ними акцентується на потребі формування найбільш оптимальної структури бюджетних видатків, створенні ефективного не надто чисельного управлінського апарату, здійсненні постійного аналізу витрачання бюджетних коштів й упередженні випадків їх нераціонального витрачання.

Показники виконання місцевих бюджетів відбивають загальний соціально-економічний стан відповідної території та іiі потенціал до сталого розвитку. Наявність достатніх ресурсів у місцевих бюджетах є запорукою того, що територіальна громада має можливість надавати більш якісні та більш різноманітні послуги своїм жителям, реалізовувати соціальні та інфраструктурні проєкти, створювати умови для розвитку підприємництва, залучення інвестиційного капіталу, розробляти програми місцевого розвитку та фінансувати інші заходи для всебічного поліпшення умов проживання жителів громади [2].

Аналіз останніх досліджень і публікацій. Останнім часом до висвітлення проблеми бюджетно-фінансової децентралізації в контексті реформування місцевого самоврядування в Україні зверталися Бедринець М. Д. (висвітлює сучасний стан і перспективи розвитку фінансової децентралізації в Україні [3], Кнір М. О. (досліджує бюджетну децентралізацію та іiі вплив на соціальноекономічний розвиток регіонів України) [4], Лопушинський I. П. ( описує нову 
парадигму місцевих бюджетів в умовах децентралізації влади в Україні) [5], Мануілова К. В., Мужайло В. Д., Бондар В. А. (розглядають оптимізацію міжбюджетних відносин як чинник сталого розвитку громад в контексті децентралізації влади в Україні) [6], Л. Синявська, О. Шолудько, М. Богач (розкривають економічні передумови та сучасний стан фінансової децентралізації) [7], Слюсарчук О. П., Криштоф Н. С., Дороніна I. I. (аналізують кількісні виміри та індикатори фінансової децентралізація в контексті реформування міжбюджетних відносин) [8], Петленко Ю. В. (вивчає фінансову децентралізацію як напрямок підвищення фінансової незалежності місцевих бюджетів) [9] та ін. Водночас, у цих та інших наукових розвідках по суті не розкривається стан фінансової децентралізації після завершення адміністративно-територіальної реформи в Україні (2020р.).

Мета статті. Попри численні наукові дослідження певні напрямки в проблематиці публічних фінансів залишаються недостатньо дослідженими. Процес становлення місцевих бюджетів супроводжується появою цілого комплексу нових теоретичних та практичних проблем, що потребують дальшого системного вивчення. Серед них - проблема бюджетно-фінансової децентралізації як дієвого чинника забезпечення сталого розвитку територіальних громад та його соціальної складової в умовах адміністративного реформування публічної влади. Саме тому метою нашої статті і став розгляд теоретичних засад та сучасної практики бюджетнофінансової децентралізації в контексті реформування місцевого самоврядування в Україні.

Виклад основного матеріалу. виконавчої влади та органів місцевого самоврядування [10, с. 166]. Як зазначає В. Я. Малиновський в Енциклопедичному словнику 3 державного управління, децентралізація (від лат. de - заперечення, centrum - основний центр) - процес передачі частини функцій та повноважень вищими рівнями управління нижчим (від центральних органів виконавчої влади до місцевих органів

Децентралізація державної влади - самостійність у підходах до управління з урахуванням місцевих особливостей під час збереження єдності в основному, суттєвому; виявляється у делегуванні повноважень від органів державного управління до органів місцевого самоврядування. На практиці вона постає як передання частини функцій державного управління центральних органів виконавчої влади місцевим органам виконавчої влади та органам місцевого самоврядування, розширення повноважень нижчих органів за рахунок вищих за рівнем [10, с. 166]

Бюджетно-фінансова децентралізація полягає в переданні джерел доходів місцевих бюджетів із державного бюджету і повноважень щодо управління ними від державних органів виконавчої влади органам місцевого самоврядування для реалізації останніми власних та делегованих державою функцій. При цьому передача нових повноважень та обов'язків (відповідно до статті 67 Закону «Про місцеве самоврядування в Україні» - aвm.) має 
підкріплюватися відповідним рівнем фінансових ресурсів і точним визначенням дохідних джерел [11, с. 43].

Як відомо, головним стратегічним завданням модернізації системи публічної влади України $\epsilon$ формування ефективного місцевого самоврядування, створення комфортних умов для проживання громадян, надання їм високоякісних та доступних публічних, соціальних послуг. У контексті реформи децентралізації влади місцевому самоврядуванню було передано нові функції, повноваження та завдання, що постали перед місцевими владними структурами після проголошення курсу на децентралізацію публічної влади. Виходячи із цього, децентралізація владних та бюджетно-фінансових повноважень держави на користь місцевого самоврядування $\epsilon$ однією із найбільш визначальних реформ 3 часів проголошення української незалежності. Досягнення зазначених цілей неможливе без належного рівня соціально-економічного розвитку відповідних територій, їх фінансового забезпечення i достатніх джерел для наповнення місцевих бюджетів з метою реалізації соціальних програм.

Отже, фінансова складова, передусім бюджетно-фінансова децентралізація є одним із найсуттєвіших чинників, від якого значною мірою залежить успішність функціонування територіальних громад (далі - ТГ), оскільки саме наявність на території ТГ економічно активних суб'єктів підприємницької діяльності, достатня кількість кваліфікованих трудових ресурсів, розвинена промислова та соціальна інфраструктура - усе це $\epsilon$ передумовою дальшого успішного розвитку громади.

У нашій державі наразі напрацьовано достатньо розгалужену нормативноправова базу, що регулює діяльність у галузі місцевих фінансів та бюджетів. Зокрема, питання бюджету в громадах закріплено у вітчизняному законодавстві, а саме: в Конституції України; у Бюджетному та Податковому кодексах, у законах про Державний бюджет на відповідний рік, «Про місцеве самоврядування в Україні», «Про місцеві державні адміністрації», «Про стимулювання розвитку регіонів», «Про засади державної регіональної політики», «Про співробітництво територіальних громад», «Про добровільне об'єднання територіальних громад», «Про асоціації органів місцевого самоврядування», а також в інших постановах, розпорядженнях та наказах Кабінету Міністрів України і Верховної Ради України.

Уперше за роки незалежності Україна підійшла безпосередньо до втілення реальних кроків щодо перерозподілу повноважень на користь регіонів і місцевої влади. Наша держава вийшла на абсолютно європейську форму місцевого самоврядування в частині фіскальної децентралізації, коли кожна місцева рада має всі права і зобов'язана ухвалювати рішення щодо наповнення своїх бюджетів та фінансування видатків.

У межах реалізації основного етапу децентралізації державної влади та реформи місцевого самоврядування 2020 року завершився процес формування адміністративно-територіального устрою базового та субрегіонального рівня. 
Після проведення чергових місцевих виборів 25 жовтня 2020 року Україна повністю покрита територіальними громадами.

Відповідно, у Державних бюджетах України на 2021 і 2022 роки вже запроваджено дворівневу модель міжбюджетних відносин (держава територіальна громада - $a в m$.) та встановлено взаємовідносини між держбюджетом та 1470 бюджетами територіальних громад.

Для досягнення цієї мети впродовж 5 років велася системна робота щодо реформування міжбюджетних відносин. 32015 року було розпочато реформування бюджетної системи в контексті децентралізації та запроваджено нову систему міжбюджетних відносин. Реформа міжбюджетних відносин та зміни до податкового законодавства, зокрема: сприяли підвищенню рівня фінансового забезпечення місцевих бюджетів; забезпечили формування нових прогресивних відносин в управлінні бюджетними ресурсами; створили умови для мотивації органів місцевого самоврядування до нарощування дохідної бази місцевих бюджетів [12].

Упродовж першого етапу за 2015-2016 роки вдалося впровадити перший етап реформи та досягти кількох важливих результатів: 1) було зміцнено фінансову спроможність місцевих бюджетів; 2) забезпечено надання якісних суспільних послуг споживачам завдяки розширення видаткових повноважень органів місцевого самоврядування [12].

Таким чином, 2016 року органи місцевого самоврядування отримали додатковий ресурс як для виконання делегованих державою повноважень, так і на виконання самоврядних функцій. Зокрема, 2016 року приріст надходжень до загального фонду проти 2015 року (у співставних умовах) становив 49,3\%, або 48,4 млрд гривень. Загалом, за підсумками 2016 року місцеві бюджети (загальний та спеціальний фонди разом) було виконано з профіцитом в обсязі 15,4 млрд гривень.

Протягом другого етапу, починаючи з 2017 року, стартував (триває до цього часу - aвm.) другий етап реформи міжбюджетних відносин. Основним завданням цього етапу є розмежування сфер відповідальності державних та місцевих органів влади щодо утримання закладів загальної середньої освіти та закладів охорони здоров'я.

На фінансування 3 місцевих бюджетів, у межах поглиблення процесу децентралізації, 3 метою забезпечення оптимального i справедливого розподілу ресурсу між усіма бюджетами та збалансування їх фінансових можливостей було передано видатки на:

- утримання закладів загальної середньої освіти, окрім видатків на оплату праці педагогічних працівників, що, починаючи з 2017 року, здійснюються за рахунок освітньої субвенції;

- оплату поточних видатків (крім комунальних послуг та енергоносіїв закладів охорони здоров'я) та інших видатків на утримання цих закладів, що здійснювалися за рахунок медичної субвенції [12].

Принагідно слід зазначити, що, починаючи 31 квітня 2020 року, відповідно до Прикінцевих та перехідних положень Бюджетного кодексу 
України, первинну, вторинну (спеціалізовану), третинну (високоспеціалізовану) та екстрену медичну допомогу за програмою державних гарантій медичного обслуговування населення передано на фінансування з державного бюджету.

2017 року приріст надходжень місцевих бюджетів проти 2016 року становив 30,9\%, або 45,3 млрд гривень.

За 2018 рік приріст, порівняно з 2017 роком, становив 21,9\%, або 42 млрд гривень.

2019 року приріст становив 17,6\%, або 41,1 млрд гривень.

Водночас порівняно із затвердженим планом на 2020 рік місцеві бюджети було виконано лише на 98,2\%, у тому числі: виконання доходів загального фонду склало 98,6\%, виконання спеціального фонду - 97,3\%. Порівняно з 2019 роком, загальні доходи місцевих бюджетів зменшилися на 89,0 млрд грн (з 560,5 до 471,5) або на $15,9 \%$. Проте зменшення відбулося за рахунок трансфертів 3 державного бюджету. 2020 року до загального фонду місцевих бюджетів надійшло 135,9 млрд грн трансфертів, що на 108,4 млрд грн (на 44,4\%) менше 2019 року. Зокрема, це пов'язано з тим, що 2020 року з місцевих бюджетів не здійснювалися окремі видатки, пов'язані з реалізацією державних програм соціального захисту, обсяг яких 2019 року склав 78,3 млрд грн [2].

У той же час уже за 11 місяців 2021 року до загального фонду місцевих бюджетів (без урахування міжбюджетних трансфертів) надійшло 316 млрд 978,5 млн гривень. Приріст надходжень до загального фонду проти січнялистопада 2020 року (у співставних умовах) склав 20,9\% або + 54 млрд 885,1 млн гривень [13].

Ще один із ключових напрямків реформи міжбюджетних відносин - це створення, як уже зазначалося вище, дворівневої моделі міжбюджетних відносин. У результаті добровільного об'єднання громад упродовж 2015-2019 років було укрупнено 3700 місцевих бюджетів. Завдяки реформі міжбюджетних відносин (станом на сьогодні) 872 територіальних громади мають новий рівень бюджетних повноважень і відносин з державним бюджетом.

Позитивним аспектом реформи міжбюджетних відносин $є$ щорічне збільшення інвестиційних ресурсів місцевих бюджетів та зростання частки видатків на виконання самоврядних повноважень, що свідчить про підвищення видаткової автономності місцевих бюджетів та ефективності використання бюджетних коштів на місцевому рівні.

Зокрема, за останні п'ять років (2016 - 2020) обсяги капітальних видатків місцевих бюджетів становили:

за 2020 рік - 96,8 млрд грн, що на 3,0 млрд гривень менше, ніж 2019 року.

за 2019 рік - 99,8 млрд грн, що на 8,6 млрд грн, або на 9,5\% більше, ніж 2018 року.

За 2018 рік - 91,2 млрд грн, що на 16,9 млрд грн, або на 22,7\% більше порівняно з 2017 роком.

За 2017 рік - 74,3 млрд грн, приріст порівняно з 2016 роком + 21,7 млрд грн, або $+41,3 \%$. 
За 2016 рік - 52,5 млрд грн. Приріст, порівняно з 2015 роком - 20,4 млрд грн, або 63,3\% [13].

Досвід зарубіжних країн свідчить, що передача повноважень від державних органів до органів місцевого самоврядування забезпечує зміцнення місцевого самоврядування та надає їм можливість ефективніше вирішувати питання розвитку своїх територій.

У непрості часи, коли увесь світ стурбований поширенням хвороби (COVID-19), спричиненої коронавірусом SARS-CoV-2, Уряд країни вживає всіх потрібних заходів щодо створення умов для виконання як центральними органами влади, так і органами виконавчої влади на місцях та органами місцевого самоврядування покладених на них функцій.

У підсумку, за сім останніх років ресурсна база органів місцевого самоврядування збільшилася в 4 рази, обсяги капітальних видатків місцевих бюджетів виросли на 60 відсотків [13]. У структурі доходів місцевих бюджетів, місцеві податки і збори становлять у середньому до $35 \%$, решта ж це надходження загальнодержавних податків і зборів [12].

Висновки. Слід зазначити, що показники виконання бюджетів відбивають загальний соціально-економічний стан відповідної території та іiі потенціал для дальшого розвитку. Наявність достатніх ресурсів у місцевих бюджетах $\epsilon$ індикатором того, що територіальна громада має можливість надавати більш якісні та більш різноманітні послуги своїм жителям, реалізовувати соціальні та інфраструктурні проєкти, створювати умови для розвитку підприємництва та залучення інвестицій, розробляти програми місцевого розвитку та фінансувати інші заходи для всебічного поліпшення умов проживання жителів громади.

Нині можна констатувати, що запровадження бюджетно-фінансової децентралізації дозволяє кошторисам органів місцевого самоврядування самим формувати дохідні статті та самостійно визначати напрямки використання отриманих коштів. Адміністративно-територіальна реформа (створення ТГ - aвm.) та бюджетно-фінансова децентралізація, відповідно до яких формуються самостійно визначені місцеві громади, ставить за потребу поступове вирішення проблеми всеохопної залежності місцевих бюджетів від центрального фінансування.

Реформа децентралізації сприяє якісному поліпшенню життєвого середовища для мешканців громад, створенню реальних умов для всебічного розвитку територій та людських ресурсів, формування засад дієвого місцевого самоврядування.

\section{Лimepamypa:}

1. Магновський I. Й. Теоретико-правові аспекти сучасного розуміння категорії "децентралізація" [Електронний ресурс] / I. Й. Магновський // Вісник Луганського державного університету внутрішніх справ імені Е. О. Дідоренка. - 2021. - Вип. 3. - С. 27-38. - Режим доступу: http://nbuv.gov.ua/UJRN/Vlduvs_2021_3_4 
2. Місцеві фінанси та бюджетна децентралізація. Сайт «Децентралізація дає можливості».URL: https://decentralization.gov.ua/finance

3. Бедринець М. Д. Фінансова децентралізація в Україні: сучасний стан і перспективи розвитку [Електронний ресурс] / М. Д. Бедринець // Наукові записки Національного університету "Острозька академія". Серія : Економіка. - 2021. - № 21. - С. 48-55. - Режим доступу: http://nbuv.gov.ua/UJRN/Nznuoa_2021_21_9

4. Кнір М. О. Бюджетна децентралізація та іï вплив на соціально-економічний розвиток регіонів України [Електронний ресурс] / М. О. Кнір, В. А. Делас, Н. А. Будник // Вісник Київського національного університету імені Тараса Шевченка. Економіка. - 2020. Вип. 5. - С. 11-18. - Режим доступу: http://nbuv.gov.ua/UJRN/VKNU_Ekon_2020_5_4

5. Лопушинський I. П. Нова парадигма місцевих бюджетів в умовах децентралізації влади в Україні // Політика та управління розвитком регіону у вимірі децентралізації влади в Україні: Збірник матеріалів міжрегіональної науково-практичної конференції: Херсон. Видавництво «ЛТ-офіс», 2018. - С. 23-27.

6. Мануілова К. В., Мужайло В. Д., Бондар В. А. Оптимізація міжбюджетних відносин як чинник сталого розвитку громад в контексті децентралізації влади в Україні // Державне управління: удосконалення та розвиток: електронне наукове фахове видання, 2021. - № 2. URL: dy.nayka.com.ua/pdf/2?2021/11/pdf

7. Синявська Л. Фінансова децентралізація: економічні передумови та сучасний стан [Електронний ресурс] / Л. Синявська, О. Шолудько, М. Богач // Вісник Львівського національного аграрного університету. Серія : Економіка АПК. - 2021. - № 28. - С. 57-61. Режим доступу: http://nbuv.gov.ua/UJRN/Vlnau_econ_2021_28_11

8. Слюсарчук О. П. Фінансова децентралізація у контексті реформування міжбюджетних відносин: кількісні виміри та індикатори [Електронний ресурс] / О. П. Слюсарчук, Н. С. Криштоф, I. I. Дороніна // Наукові записки Інституту законодавства Верховної Ради України. - 2021. - № 1. - С. 143-154. - Режим доступу: http://nbuv.gov.ua/UJRN/Nzizvru_2021_1_16

9. Петленко Ю. В. Фінансова децентралізація як напрямок підвищення фінансової незалежності місцевих бюджетів [Електронний ресурс] / Ю. В. Петленко, В. Міланченко // Вісник Київського національного університету імені Тараса Шевченка. Економіка. - 2020. Вип. 4. - С. 39-47. - Режим доступу: http://nbuv.gov.ua/UJRN/VKNU_Ekon_2020_4_5

10. Енциклопедичний словник з державного управління / уклад.: Ю. П. Сурмін, В. Д. Бакуменко, А. М. Михненко та ін.; за ред. Ю. В. Ковбасюка, В. П. Трощинського, Ю. П. Сурміна. - К.: НАДУ, 2010. - 820 с.

11. Мізіна I. В. Фінансова децентралізація та їі вплив на систему місцевих фінансів України // Аспекти публічного управління, 2016. - № 6-7. - С. 41-48.

12. Улютін Денис. Бюджетна децентралізація: головні виклики та досягнення. URL: https://decentralization.gov.ua/news/12661

13. Виконання доходів місцевих бюджетів. Сайт Міністерства фінансів України. URL: https://mof.gov.ua/uk/vykonannia-dokhodiv-mistsevykh-biudzhetiv

\section{References:}

1. Magnovsky I.Y. (2021). Teoretyko-pravovi aspekty suchasnoho rozuminnya katehoriyi "detsentralizatsiya" [Theoretical and legal aspects of modern understanding of the category "decentralization"]. Visnyk Luhans'koho derzhavnoho universytetu vnutrishnikh sprav imeni E. O. Didorenka - Bulletin of Lugansk State University of Internal Affairs named after EA Didorenko, 3, 27-38. Retrieved from http://nbuv.gov.ua/UJRN/Vlduvs_2021_3_4 [in Ukrainian].

2. Local finances and budget decentralization. The site "Decentralization provides opportunities". URL: https://decentralization.gov.ua/finance

3. Bedrynets M.D. (2021). Finansova detsentralizatsiya v Ukrayini: suchasnyy stan i perspektyvy rozvytku [Financial decentralization in Ukraine: current status and prospects]. 
Naukovi zapysky Natsional'noho universytetu "Ostroz'ka akademiya". Seriya : Ekonomika Scientific notes of the National University "Ostroh Academy". Series: Economics, 21, 48-55. Retrieved from http://nbuv.gov.ua/UJRN/Nznuoa_2021_21_9 [in Ukrainian].

4. Knir M. O., Delas V.A., \& Budnyk N.A. (2020). Byudzhetna detsentralizatsiya ta yiyi vplyv na sotsial'no-ekonomichnyy rozvytok rehioniv Ukrayiny [Budget decentralization and its impact on socio-economic development of the regions of Ukraine]. Visnyk Kyyivs'koho natsional'noho universytetu imeni Tarasa Shevchenka. Ekonomika - Bulletin of the Taras Shevchenko National University of Kyiv . Economy, 5, 11-18. Retrieved from http://nbuv.gov.ua/UJRN/VKNU_Ekon_2020_5_4[in Ukrainian].

5. Lopushinsky I.P. (2018). Nova paradyhma mistsevykh byudzhetiv $\mathrm{v}$ umovakh detsentralizatsiyi vlady $\mathrm{v}$ Ukrayini [A new paradigm of local budgets in terms of decentralization of power in Ukraine]. Proceedings from the interregional scientific-practical conference: Polityka ta upravlinnya rozvytkom rehionu u vymiri detsentralizatsiyi vlady v Ukrayini - Policy and management of regional development in the dimension of decentralization of power in Ukraine. (pp. 23-27). Kherson: LT-Office Publishing House [in Ukrainian].

6. Manuilova K.V., Muzhailo V.D., \& Bondar V.A. (2021). Optymizatsiya mizhbyudzhetnykh vidnosyn yak chynnyk staloho rozvytku hromad $\mathrm{v}$ konteksti detsentralizatsiyi vlady v Ukrayini [Optimization of intergovernmental relations as a factor of sustainable development of communities in the context of decentralization of power in Ukraine]. Derzhavne upravlinnya: udoskonalennya ta rozvytok: elektronne naukove fakhove vydannya - Public administration: improvement and development: electronic scientific professional publication, 2. Retrieved from http://dy.nayka.com.ua/pdf/2?2021/11/pdf [in Ukrainian].

7. Sinyavska L., Sholudko O., \& Bogach M. (2021). Finansova detsentralizatsiya: ekonomichni peredumovy ta suchasnyy stan [Financial decentralization: economic prerequisites and current status]. Visnyk L'vivs'koho natsional'noho ahrarnoho universytetu. Seriya : Ekonomika APK - Visnyk of Lviv National Agrarian University. Series: Economics of agro-industrial complex, 28, 57-61. Retrieved from http://nbuv.gov.ua/UJRN/Vlnau_econ_2021_28_11 [in Ukrainian].

8. Slyusarchuk O.P., Kryshtof N.S., \& Doronina I.I. (2021). Finansova detsentralizatsiya u konteksti reformuvannya mizhbyudzhetnykh vidnosyn: kil'kisni vymiry ta indykatory [Financial decentralization in the context of reforming intergovernmental relations: quantitative dimensions and indicators]. Naukovi zapysky Instytutu zakonodavstva Verkhovnoyi Rady Ukrayiny - Scientific notes of the Institute of Legislation of the Verkhovna Rada of Ukraine, 1, 143-154. Retrieved from http://nbuv.gov.ua/UJRN/Nzizvru_2021_1_16 [in Ukrainian].

9. Petlenko Yu.V. \& Milanchenko V. (2020). Finansova detsentralizatsiya yak napryamok pidvyshchennya finansovoyi nezalezhnosti mistsevykh byudzhetiv [Financial decentralization as a direction of increasing the financial independence of local budgets]. Visnyk Kyyivs'koho natsional'noho universytetu imeni Tarasa Shevchenka. Ekonomika - Visnyk of Kyiv National Taras Shevchenko University. Economy, 4, 39-47. Retrieved from http://nbuv.gov.ua/UJRN/VKNU_Ekon_2020_4_5 [in Ukrainian].

10. Surmin Yu. P., Bakumenko V.D., Mikhnenko A.M., et al . (2010). Entsyklopedychnyy slovnyk $z$ derzhavnoho upravlinnya [Encyclopedic Dictionary of Public Administration]. Yu. V. Kovbasyuk, V.P. Troshchynsky, Yu. P. Surmin (Ed.). K .: NADU. [in Ukrainian].

11. Mizina I.V. (2016). Finansova detsentralizatsiya ta yiyi vplyv na systemu mistsevykh finansiv Ukrayiny [Financial decentralization and its impact on the system of local finance of Ukraine]. Aspekty publichnoho upravlinnya - Aspects of public administration, (№ 6-7), (pp. 41-48) [in Ukrainian].

12. Ulyutin Denis. Byudzhetna detsentralizatsiya: holovni vyklyky ta dosyahnennya [Budget decentralization: main challenges and achievements]. (n. d.). Retrieved from https://decentralization.gov.ua/news/12661 [in Ukrainian]. 
13. Vykonannya dokhodiv mistsevykh byudzhetiv [Execution of local budget revenues]. (n. d.). Sayt Ministerstva finansiv Ukrayiny - Website of the Ministry of Finance of Ukraine. Retrieved from https://mof.gov.ua/en/vykonannia-dokhodiv-mistsevykh-biudzhetiv [in Ukrainian]. 